USOBED Uluslararası Batı

Research Article Araştırma Makalesi
Karadeniz Sosyal ve Beşeri Bilimler Dergisi, 3(2): 204-217,

31 Aralık-December, 2019
International Journal of Western Black Sea Social and Humanities Sciences e-ISSN :2602-4594

\title{
REKLAM VE ETKİLİ REKLAM UNSURLARININ BELİRLENMESINNE YÖNELİK UYGULAMALI BİR ARAŞTIRMA ${ }^{1}$
}

\author{
Doç. Dr. Abdulvahap BAYDAŞ \\ Düzce Üniversitesi, İşletme Fakültesi \\ abdulvahapbaydas@.düzce.edu.tr \\ ORCID:0000-0002-4471-3470
}

\section{Öğr. Gör. Mehmet Emin YAŞAR*}

Solhan SHMY, Sağlık Bilimleri Fakültesi

meyasar@bingol.edu.tr

ORCID:0000-0001-8137-2946

\section{$\ddot{O} \mathbf{z}$}

Araştırma reklam mecralarının etkinliği ve reklam mecralarının tüketici satın alma davranışı etkisi reklamda etkili olan unsurlarla tespit edilmeye çalış1mıştır. Söz konusu amaca ulaşmak için reklam mecraları, reklam mecralarında takip edilen program türleri, reklamda ilgili unsur ile reklam mesajlarında en çok ilgi çeken unsur araştırılmıştır. Araştırma kolayda örneklem yöntemi kullanılarak 385 tüketici ile yürütülmüştür. Sahadan toplanan veriler SPSS paket programı aracılığıyla analiz edilmiştir. Araştırmadan çıkan en önemli sonuçlar; bilgi edinmenin önemi sırası ile mobil iletişimde bilgi edinme, radyo dinlerken bilgi edinme, gazete okurken bilgi edinme, televizyon izleme, internette bilgi edinme ve dergi okumanın önemi vurgulanmıştır.

Tüketiciler televizyon, dergi, gazete, internet ve mobil iletişim araçları aracılığıyla haber ve ekonomi programlarını takip etmektedir. Ayrıca, Talk Show programlarının ise daha sonra tercih edildiği belirlenmiştir. Reklamda en çok ilgi çeken unsurun güldürü olduğu söylenebilir. Reklam mesajlarında en çok ilgi çeken unsurun reklamda mizahi unsurların kullanılması, etkin müzik ve ses, reklamda gösterimindeki renkler olduğu en az ilgi çeken unsurun reklamın istenilen saatte çıkmasıdır. Bu bağlamda katılımcıların reklamda en çok ilgilerini çeken unsurun mizah içerikli görsellerin olduğu söylenebilir.

\footnotetext{
${ }^{1}$ Bu çalışma "Uluslararası 29 Ekim Bilimsel Araştırmalar Sempozyumu 26-29 Ekim 2019, İzmir” Sempozyumunda sunulan ve Tam Metin Kitabında Yayınlanan sunumun geliştirilmiş halidir.
} 
Anahtar Kelimeler: Sosyal medya, sosyal medya reklamları, etkili reklam mecraları

\title{
AN APPLIED RESEARCH ON DETERMINATION OF ADVERTISING AND EFFECTIVE ADVERTISING COMPONENTS
}

\begin{abstract}
The research has tried to determine the effectiveness of advertising media and the effect of consumer buying behavior of advertising media with the elements that are effective in advertising.In order to achieve this objective, important issues such as advertising sources, the types of programs followed, the elements of interest in advertisements and the elements of the most interest in advertisements were investigated. The data of the study was obtained from 385 consumers by using easy sampling method. The results were analyzed with SPSS package program. The most important results of the research is the importance of obtaining information from following sources, respectively; acquiring information by mobile communication, acquiring information while listening to radio, acquiring information while reading newspapers, watching television, acquiring information on the internet and acquiring information by reading magazines.

Consumers follow news and economic programs through television, magazines, newspapers, the internet and mobile communications. After news, talk show programs were found to be watched most. It can be said that while the most interesting elements in advertisements are a visual with comedy content and the use of appropriate music and sound, the advertisement's appearing at the desired time is the least interesting element. In this context, it can be claimed that for the participants the most interesting element of the advertising is the humorous visuals.
\end{abstract}

Keywords: Social media, social media advertising, effective advertising sources

\section{Giriş}

Pazarlama iletişimi stratejilerinin uygulanması ülkeden ülkeye değişiklik gösterdiği gibi işletmeden işletmeye ve sektörden sektöre farklılık göstermektedir. Küresel işletmelerin sektörlerde etkin çalışması yerel işletmeleri de yeni pazarlama iletişimi çalışma ve uygulamalarına itmiştir (Keegan ve Green, 2015). Özellikle küresel işletmeler ve küresel işletmelere ait reklam ajansları sınır ötesinde iletişimde bulunmak üzere pazarlama iletişimine büyük önem vermektedirler.

İşletmeler sahip oldukları ürün, hizmet, değer, marka vb. konuları hedef kitlelere duyurma ihtiyacına sahiptir. Duyurum ihtiyaçlarını pazarlama iletiş araçları olarak tanımlanan elemanlarla gerçekleştirmektedirler. Pazarlama iletişimi araçları, reklam, kişisel satış, satış 
artırma çabaları, halkla ilişkiler ve doğrudan tanıtım faaliyetleridir. Reklam ve reklam faaliyetleri pazarlama iletişimin en önemli bileşenlerinden biridir. Özellikle kitle iletişim mecraları aracılığı ile büyük sayıdaki bireylere çok kısa bir sürede ulaşılma özelliği açısından oldukça tercih edilen pazarlama iletişimi unsurudur.

İşletmeler hedef müşteri kitlesiyle daha etkili bir iletişim sağlamak için farklı iletişim mecraları vasıtasıyla mesaj göndermektedirler. Gelişen teknoloji sonucu küçük ya da finansal açıdan güçsüz olan işletmeler de rakipleriyle benzer ürün ve hizmet üretmektedirler. Bu durum da rekabeti daha da yoğun hale getirmiştir. Teknolojide meydana gelen ilerlemeler; iletişim araçlarının gelişmesine etkide bulunmuş ve bunun sonucu olarak iletişim teknolojisinde muazzam gelişmelere neden olmuştur. Ayrıca iletişim ortamları da değişmekte, iletişim ve haberleşme için geleneksel yöntemlerin yerine yeni iletişim kanalları gelmiştir. Yeni bilgi işlem ve haberleşme kanalları arasında Facebook, Twitter, Instagram, bloklar vb. sosyal ağlar yer almaktadır. İletişim yüz yüze tekniklerin yerine geçen çevrimiçi iletişim ortamları yer almıştır (Göktaş, 2017).

Reklam aracılığı ile kurumlar geniş hedef kitleye mal, hizmet, kurum ya da markalarını duyurmaktadırlar. Reklam mesajlarının doğru reklam mecralarında ve doğru zamanda hedef müşteri kitlesine ulaştırılmasıyla kurum, ürün veya marka ile müşteri arasında olumlu ilişki oluşabilecektir. İşletmeler tarafından çok yoğun olarak kullanılan bu reklam şeklinin hedef kitle tarafından benimsenip benimsenmediği (Gürdin, 2017) araştırılmamakta, incelense de önemli unsurları dikkate alınmamaktadır.

Günümüzde geniş halk kitleleri ile iletişim, tüm kurum ve kuruluşlar için büyük önem taşımaktadır (İslamoğlu, 2011). Reklamın tüketicilere bilgi verme yanında, onları ikna etme ve ürüne değer katmaya yönelik olarak, tüketicilerin hislerine de yoğun biçimde hitap etmektedir (Altunışık, Ödemir ve Torlak, 2006). Dolayısıyla yoğun rekabet ortamında işletme ya da kurumların reklama ve etkin reklam mecralarına olan ihtiyaçları hayati önem taşımaktadır. Ancak reklamların ve reklam mecralarının hedef kitle tarafından ne ölçüde takip edildiği, etkilendiği ve reklamı yapılan ürün ve değerin ne ölçüde tercih edildiği, tüketici tercihini etkileyen unsurların neler olduğunun bilinmesi de işletmeler açısından oldukça önemlidir.

$\mathrm{Bu}$ bağlamda araştırmanın ana amacı etkin olan reklam mecralarının tespiti, reklam mecraları ve etkili reklamların tüketici satın alma davranışı üzerindeki etkisi reklamda etkili olan unsurlarla tespit edilmeye çalışılmıştır. Söz konusu amaca ulaşmak için reklam mecraları, reklam mecralarında 
takip edilen program türleri, reklamda ilgi unsur ile reklam mesajlarında en çok ilgi çeken unsur araştırılmıştır.

\section{Kavramsal Çerçeve}

\subsection{Reklam}

Reklam hedef müşteri kitlesi ile iletişim kurmanın en iyi eski ve en etkin yoludur. Reklamların önemli bir kısmı doğrudan tüketicilere yönelik olabileceği gibi, bazı reklamlar aracı kurumlar veya işletmelere yönelik olabilir. Tüketicilere yönelik reklamlar çekme stratejisi olarak isimlendirilebilir. Çekme stratejisinde amaç, tüketicilerin mağazalardan reklamı yapılan ürünleri talep edilmesini sağlamaktır. İşletme ya da aracı kurumlara yönelik reklamlar ya da kişisel satış elemanları promosyon ve uygulamaları ise itme stratejisi olarak isimlendirilir. $\mathrm{Bu}$ stratejinin amacı, aracıların ürünü satmaya özendirilmesidir (Yoldaş ve Özaydın, 2017:784).4780

\subsection{Reklam Mecraları}

Piyasada benzer ürün veya hizmetin üretildiği çok sayıda seçenek bulunmaktadır. Söz konusu seçeneklerin pazarlanması daha çok önem kazanmıştır. Tüketiciler üretilen ürün veya hizmet içinden birini tercih etmelerinde en önemli olan etkin reklam veya tanıtım mecralarıdır. Reklam çalışmaları "Pazarlama İletişimi” algısı (MÜSİAD, 2010) üzerinden yürütülecek süreçte ürünün farklılaştırılması ve rakip ürünlerine göre tercih edilmesi önem kazanmıştır.

Toplam televizyon yayınının \% 16 ila 20'si reklamlardan oluşmaktadır. Tek kanal TV dönemlerinde izleyicilerin \% 80 veya \% 90'ına ulaşmak mümkünken, günümüzde en çok izlenen ilk dört kanalın izleyici oranı yaklaşık olarak \% 40’tır (MÜSİAD, 2010).

Yoğun rekabetin yaşandığı günümüzde tek bir reklam mecrayla hedef kitleye ulaşmak ve bu kitle üzerinde kalıcı ve hatırlanabilir bir etki bırakabilmek mümkün görülmemektedir. Sürekli reklama maruz kalan bireyler artık birçok reklamı görmemekte veya farkında dahi varmamaktadırlar. Sadece bir günde televizyon, gazete, dergi, kullanılan bilgisayar hatta sokak vb. yerlerde bireyler binlerce reklama maruz kalan tüketiciler belli bir marka veya ürünün reklamını hatırlamakta sıkıntı çekmektedirler.

Pazarlamasının önemli olduğu bir günümüzde reklama yapılan harcama tüketim harcaması olarak değil, yatırım harcaması olarak değerlendirilmektedir. KOBİ'ler bile yıllık bilançolarını hazırlarken reklam yatırımlarına yer vermek zorunda kalmışlardır. 
Hedef kitleye ulaşmanın oldukça zorlaştı̆̆ı, reklam izlenilirlik ve hatırlanırlığının azaldığ 1 ortamda işletmeler alışılmış ve gelenekselleşmiş mecraların dışında çok daha farklı reklam mecralarına yönelmektedir. Artık her türlü obje ve nesneyi bir alternatif reklam mecrası olarak değerlendirmek mümkündür. Reklamın girmediği bir alan neredeyse kalmamıştır; çarşı, pazar, kaldırım, taksi, belediye otobüsü, balon, tuvalet, stat, izlenilen dizilerde sanal reklam, eşantiyon olarak dağıtılan kalem vb., sahadaki oyuncunun sırtındaki formada marka, kurum ve ürün reklamını görmek mümkündür.

Reklam mecraları geleneksel ve geleneksel olmayan ya da ana mecra ve destek mecra şeklinde iki ana gruba ayrılabilir. Televizyon, gazete, dergi, radyo, doğrudan postalama, internet ve açık alan (outdoor) vb. geleneksel reklam mecraları olarak kabul edilmektedir (Raudeliuniene', Davidavi־ciene, Tvaronavi`cien`e ve Jonuška, 2018).

Geleneksel ya da destek reklam mecraları: Mobil araçlar, interaktif ortamlar, blog ve vlogları, satış noktası, sosyal ağlar, sinema ve film mecraları en çok bilinenlerdir. Ayrıca bu mecralar reklam vermeyen kitleleri birer reklam veren konumuna getirmiştir (Can ve Serhateri, 2016; Lakshmanan ve Basariya, 2017; Süar, 2017).

Geleneksel olmayan reklam mecraların kullanımı ile daha az maliyetle reklam yapılabilmekte ve hedef kitleye ulaşılabilmektedir. Reklamların işlevlerinden biri olarak kabul edilen ihtiyaç oluşturma özelliği ile tüketicilerin almak istemediği veya ihtiyaç hissetmediği bir malı veya hizmeti de satın alabilmektedir. En önemli örnek çamaşır makineleri için satın alınan kireç sökücülerdir (MÜSİAD, 2010). Ayrıca çamaşır makinesi için alınan deterjanlar: Beyaz giysilere, renkli giysilere, leke çıkartmaya, mis gibi kokutucu, yumuşatıcı, hassas giysilere vb. deterjan kullanmak mümkündür.

Tüketicinin ihtiyaç ve isteklerini karşılamayı amaçlayan kurumların kullandığı (Tekin vd., 2014:227), yeni müşteri kazanmak için kısa dönemli pazarlama faaliyetleri yerine, uzun süreli müşteriyi elde tutma çabaları (Gronross, 1995:252) modern pazarlama anlayışı olan ilişkisel pazarlama alternatif reklam mecralarının gelişmesine imkan tanımıştır.

\section{Reklam ve Etkili Reklam Unsurlarının Belirlenmesine Yönelik Uygulamalı Bir}

\section{Araştırma}

\subsection{Araştırmanın Amaç ve Kapsamı}

Araştırma sosyal medyada gerçekleşen pazarlamanın iletişim faaliyetlerinden biri olan reklamların sosyal medya kullanıcıları tarafından dikkat çekiciliğinin ölçümlenmesi amacıyla yapılmıştır. Sosyal medyada sürekli reklam, tanıtım ve bilgilendirmeye maruz kalan tüketiciler, 
kendilerine ulaşan ve kararlarının değişmesi için ikna edilmeye çalışan kişilerin söz konusu uygulamalardan etkilenip, etkilenmedikleri ve etkilenme düzeylerinin tespit edilmesi ana amaçlar arasında yer almaktadır. Bu amaçla hazırlanan anket formu genel olarak; konu ile ilgili genel ifadeleri, reklam ve sosyal medya mecraları, sosyal medya reklamlarında ilgi çeken konular ve unsurlar dikkate alınmıştır.

\subsection{Araştırmanın Önemi}

Rekabette meydana gelen yoğunluk ve şiddet işletmeleri müşteri odaklı olmaya zorlamıştır. Müşteri odaklılık, müşteriyi işlemlerin odağına alarak ona göre faaliyetlerde bulunma ve stratejiler geliştirmesini gerektirmektedir. Bu bağlamda işletmelerin müşteri perspektifinden değerlendirme, işletme ve sektör açısından hayati öneme sahiptir. Bu çalışmaya göre varılan sonuçlar, işletmelerin müşteri odaklı stratejiler geliştirmelerine katkı sunacak, bu konuda literatüre pozitif bir katkı yapacaktır.

\subsection{Araştırmanın Yönetimi}

Araştırma sosyal medyadaki pazarlama iletişim elemanlarından biri olan reklamların sosyal medya kullanıcıları tarafından dikkat çekiciliğinin belirlenmesi amacıyla yapılmıştır. Araştırmanın ana ve yan amaçlarının tespit edilmesi için bir anket oluşturulmuş, "tesadüfi olmayan örneklem yöntemlerinden kolayda örnekleme yöntemi” kullanılarak 385 katılımcıya ulaşılmıştır. Araştırmaya konu sosyal medya ve reklam ilişkisi daha çok ele alınmıştır. Anket Formunda öncelikle katılımcıların demografik özelliklerini belirlemeye ilişkin 6 ifade yer almış, reklam mecraları ile ilgili 6 ifade, altı reklam mecrasında takip edilen programlarla ilgili 5 ifade, reklamın ilgi çekme durumu ile ilgili 1 ifade, reklamlarda en çok ilgi çekilen unsurlarla ilgili 9 ifade (söz konusu ifadeler 5'li Likert tipi ölçek soruları 1: Çok önemli, 5: Hiç önemli değil) yer almıştır.

\subsection{Araştırmanın Bulguları}

Tablo 1: Araştırmanın genel profili

\begin{tabular}{|l|r|r|l|l|r|r|}
\hline Eğitim & Frekans & Oran & Meslek & Frekans & Oran \\
\hline İlkokul mezunu & 39 & 10,1 & Esnaf & 173 & 44,9 \\
\hline Lise mezunu & 179 & 46,5 & Devlet memuru & 110 & 28,6 \\
\hline Yüksekokul mezunu & 134 & 34,8 & & Öğrenci & 21 & 5,5 \\
\hline Fakülte mezunu & 26 & 6,8 & & Doğal gazcı & 30 & 7,8 \\
\hline Yüksek lisans ve Doktora & 7 & 1,8 & & Pazarlamac1 & 51 & 13,2 \\
\hline
\end{tabular}




\begin{tabular}{|l|r|r|l|l|r|}
\hline Toplam & 385 & \multicolumn{1}{|l|}{100,0} & Toplam & 385 & 100,0 \\
\hline Yaş & & & Medeni Hal & & \\
\hline 19 yaşından küçük & 18 & 4,7 & Bekâr & 108 & 28,1 \\
\hline $19-25$ & 115 & 29,9 & Evli & 277 & 71,9 \\
\hline 25 yaş ve üstü & 252 & 65,5 & Toplam & 385 & 100,0 \\
\hline Toplam & 385 & 100,0 & Gelir & & \\
\hline Cinsiyet & & & 2020 £ den az & 45 & 11,7 \\
\hline Erkek & 250 & 64,9 & $2021-4000$ & 190 & 49,4 \\
\hline Kadın & 135 & 35,1 & $4001-6000$ & 119 & 30,9 \\
\hline Toplam & 385 & 100,0 & 6001 £ ve üzeri & 31 & 8,0 \\
\hline & & & Toplam & 385 & 100,0 \\
\hline
\end{tabular}

Sosyal medya ve reklam ilişkisi verilerinden elde edilen sonuçlar; yaş, cinsiyet, medeni durum, meslek, eğitim ve gelir durumu frekans (f) değerleri esas alınarak belirlenmiştir. Katılımcıların cinsiyetleri \% 64,9 erkek, \% 35,1 kadın olduğu, yaş aralıkları \% 65,5'nin 25 yaş ve üstü, \% 29,9'nun 19-25 yaş, \% 4,7'sinin 19 yaşından küçük olduğu belirlenmiştir. Katılımcıların \% 71,9’u evli, \% 28,1'i bekâr olduğu ifade edilmiştir. Deneklerin \% 46,5'i lise mezunu, \% 34,8'i yüksekokul mezunu, \% 10,1'i ilkokul mezunu, \% 6,8'i fakülte mezunu, \% 1,8'i yüksek lisans ve doktora eğitimine sahiptir. Meslek açısından \% 44,9'nun esnaf, \% 28,6's1 devlet memuru, \% 13,2'si pazarlamacı, \% 7,8'i doğal gazc1, \% 5,5'i öğrenci olduğu tespit edilmiştir. Cevaplayıcıların \% 49,4’ü 2021-4000 £, gelire sahipken, \% 30,9’u 4001-6000 gelir, \% 11,7’si 2020 € den az, \% 8'i 6001 € ve üzeri gelire sahiptir.

Özetle katılımcıların önemli bir kısmı erkek (\% 64,9), evli (\% 71,9), lise mezunu eğitimine sahip (\% 46,5), önemli bir kısmı esnaf (\% 44,9), gelir seviyelerinin 2021-3000 gelire sahip olduğu $(\% 49,4)$ görülmektedir.

Tablo 2: Reklam mecralarında bilgi edinmenin öneminin karşılaştırılması

\begin{tabular}{|c|c|c|c|c|c|c|c|}
\hline & & 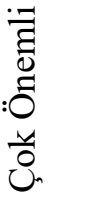 & $\begin{array}{l}: \overline{\bar{\Xi}} \\
\text { : }\end{array}$ & 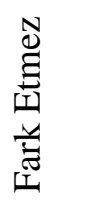 & 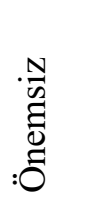 & 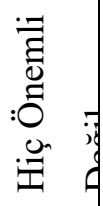 & $\begin{array}{l}\frac{\Xi}{0} \\
\frac{\tilde{a}}{0} \\
\stackrel{0}{0}\end{array}$ \\
\hline \multirow[t]{2}{*}{ Televizyon izlemenin önemi } & Frekans & 194 & 146 & 35 & 5 & 5 & 385 \\
\hline & Oran & 50,4 & 37,9 & 9,1 & 1,3 & 1,3 & 100,0 \\
\hline \multirow[t]{2}{*}{ Dergi okumanın önemi } & Frekans & 125 & 104 & 61 & 15 & 80 & 385 \\
\hline & Oran & 32,5 & 27,0 & 15,8 & 3,9 & 20,8 & 100,0 \\
\hline
\end{tabular}




\begin{tabular}{|l|l|r|r|r|r|r|r|}
\hline İnternette bilgi edinmenin önemi & Frekans & 226 & 112 & 26 & 6 & 15 & 385 \\
\cline { 2 - 7 } & Oran & 58,7 & 29,1 & 6,8 & 1,6 & 3,9 & 100,0 \\
\hline \multirow{2}{*}{$\begin{array}{l}\text { Mobil iletişimde bilgi edinilmenin } \\
\text { önemi }\end{array}$} & Frekans & 165 & 179 & 27 & 11 & 3 & 385 \\
\cline { 2 - 8 } $\begin{array}{l}\text { Radyo dinlerken bilgi edinilmenin } \\
\text { önemi }\end{array}$ & Oran & 42,9 & 46,5 & 7,0 & 2,9 & 0,8 & 100,0 \\
\hline \multirow{2}{*}{ Gazete okurken bilgi edinmenin önemi } & Frekans & 156 & 149 & 50 & 19 & 11 & 385 \\
\cline { 2 - 8 } & Oran & 40,5 & 38,7 & 13,0 & 4,9 & 2,9 & 100,0 \\
\cline { 2 - 8 } & Oran & 199 & 142 & 29 & 10 & 5 & 385 \\
\hline
\end{tabular}

Televizyon izlemenin (çok önemli ve önemli olan olumlu ifadeler toplanarak oran belirlenmiştir) önemli olduğunu belirtenlerin oranı $\% 88,3$ iken dergi okumanın ise $\% 59,5$ 'tir. İnternette bilgi edinmenin oran $1 \% 86,8^{\prime}$ dir. Mobil iletişimde bilgi edinmenin oranı \% 89,4'tür. Radyo dinlerken bilgi edinmenin oranı \% 89,2'dir. Gazete okurken bilgi edinmenin oranı \% 88,6'dır. Dolayısıyla mobil iletişim araçlarını takip ederken, radyo dinlerken, gazete okurken, televizyon izlerken ve dergi okurken bilgi edinmenin önem sırasına göre dizildiği söylenebilir.

Tablo 3: Reklam mecralarında takip edilen programların dağılımı

\begin{tabular}{|c|c|c|c|c|c|c|c|}
\hline & & 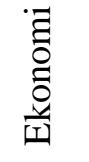 & $\begin{array}{l}\dot{\bar{\Xi}} \\
\stackrel{\tilde{\pi}}{\pi}\end{array}$ & 苑 & 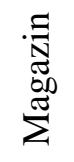 & 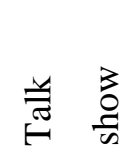 & $\frac{\Xi}{\frac{\pi}{2}}$ \\
\hline \multirow{2}{*}{$\begin{array}{l}\text { Televizyonda izlenen program } \\
\text { türü }\end{array}$} & Frekans & 148 & 194 & 24 & 8 & 11 & 385 \\
\hline & Oran & 38,4 & 50,4 & 6,2 & 2,1 & 2,9 & 100,0 \\
\hline \multirow[t]{2}{*}{ Dergide okunan program türü } & Frekans & 95 & 174 & 37 & 14 & 65 & 385 \\
\hline & Oran & 24,7 & 45,4 & 9,6 & 3,6 & 16,9 & 100,0 \\
\hline \multirow{2}{*}{$\begin{array}{l}\text { İnternette bilgi edinilen } \\
\text { program türü }\end{array}$} & Frekans & 108 & 221 & 33 & 15 & 8 & 385 \\
\hline & Oran & 28,1 & 57,4 & 8,6 & 3,9 & 2,1 & 100,0 \\
\hline \multirow{2}{*}{$\begin{array}{l}\text { Mobil iletişimde bilgi edinilen } \\
\text { program türü }\end{array}$} & Frekans & 113 & 195 & 28 & 35 & 14 & 385 \\
\hline & Oran & 29,4 & 50,6 & 7,3 & 9,1 & 3,6 & 100,0 \\
\hline \multirow{2}{*}{$\begin{array}{l}\text { Radyo dinlerken bilgi edinilen } \\
\text { program türü }\end{array}$} & Frekans & 114 & 176 & 51 & 33 & 11 & 385 \\
\hline & Oran & 29,6 & 45,7 & 13,2 & 8,6 & 2,9 & 100,0 \\
\hline \multirow{2}{*}{$\begin{array}{l}\text { Gazete okurken bilgi edinilen } \\
\text { program türü }\end{array}$} & Frekans & 164 & 168 & 29 & 22 & 2 & 385 \\
\hline & Oran & 42,6 & 43,6 & 7,5 & 5,7 & 0,5 & 100,0 \\
\hline
\end{tabular}

Katılımcıların önemli bir kısmı televizyonda izlendiğinde takip edilen programın 'haber' $(\%$ 50,4) ve ekonomi $(\% 38,4)$ olduğu görülmektedir. Dergi okunduğunda takip edilen programin 'haber' (\% 45,4) ve ekonomi (\% 24,7) olduğu talk showun ise \% 16,9'da kaldığ1 
görülmektedir. İnternette sörf yapıldığında takip edilen programın 'haber' (\% 57,4) ve ekonomi (\% 28,1) olduğu görülmektedir. Mobil iletişimde bilgi edinilen programın \% 50,6's1 'haber', \% 29,4'nün ise ekonomi ile ilgilendikleri görülmektedir. Radyo dinlerken bilgi aldıkları program \% 45,7'si 'haber', \% 29,6'sının ise ekonomi ile ilgilendikleri görülmektedir. Gazete okurken bilgi aldıkları program \% 43,6 'haber', \% 42,6 ‘ekonomi', olduğu, \% 0,5'i 'talk Show' olduğu tespit edilmiştir.

Tablo 4: Reklamın ilgi çekme durumu

\begin{tabular}{|l|r|r|}
\hline & \multicolumn{1}{|c|}{ Frekans } & \multicolumn{1}{c|}{ Oran } \\
\hline Güldüren & 281 & 72,9 \\
\hline Seri film & 89 & 23,1 \\
\hline Çizgi film kahramanı & 15 & 3,9 \\
\hline Toplam & 385 & 100,0 \\
\hline
\end{tabular}

Reklamda en çok ilgi çeken unsurun \% 72,9 güldürü olduğu, \% 23,1'nin ise seri film olduğu görülmektedir. Dolayısıyla reklamda en çok ilgi duyulan özelliğin güldürü olduğu söylenebilir.

Tablo 5: Reklamda en çok ilgi çekilen unsur

\begin{tabular}{|l|r|r|}
\hline & Frekans & \multicolumn{1}{|c|}{ Oran } \\
\hline Reklamda kullanılan müzik ve ses & 70 & 18,2 \\
\hline Reklamda kullanılan renkler & 43 & 11,2 \\
\hline Reklam ilanında kullanılan karikatürlerin ünlü olması & 19 & 4,9 \\
\hline Reklamda mizah içerikli bir görsel olması & 211 & 54,8 \\
\hline Reklamın yayınlanma sıklığı & 14 & 3,6 \\
\hline Reklamın süresi & 2 &, 5 \\
\hline Reklamlarda ünlülerin kullanılması & 8 & 2,1 \\
\hline Reklamın sevdiğim saatte çıkması & 4 & 1,0 \\
\hline Diğer & 14 & 3,6 \\
\hline Toplam & 385 & 100,0 \\
\hline
\end{tabular}

Tablo 5'te ankete verilen cevaplar incelendiğinde reklamda en çok ilgi çeken unsurun \% 54,8'i reklamda mizah içerikli bir görsel olması, reklamda kullanılan müzik ve ses \% 18,2, reklamda kullanılan renkler \% 11,2 olduğu en az ilgi çeken unsurun reklamın istenilen saatte çıkmasıdır. Bu bağlamda katılımcıların reklamda en çok ilgilerini çeken unsurun mizah içerikli görsellerin olduğu tespit edilmiştir. 
Tablo 6: Reklamda ilgi çeken unsurların; Ortalama Değer, Standart Sapma ve Katılım Düzeyi

\begin{tabular}{|l|r|r|c|}
\hline & Ortalama & Standart Sapma & Kat1lım Düzeyi \\
\hline Güldüren & 4,60 & 0,815 & Yüksek \\
\hline Seri film & 2,14 & 1,107 & Düşük \\
\hline Çizgi film kahramanı & 1,19 & 1,338 & Düşük \\
\hline
\end{tabular}

$\left(\mathrm{x}^{-}=1,00-2,33\right.$ Düşük Katılım Düzeyi, $\mathrm{x}^{-}=2,34-3,66$ Orta Katılım Düzeyi, $\mathrm{x}^{-}=3,67-$ 5,00 Yüksek Katılım Düzeyi)

Reklamın dikkat çeken yönleri açısından en önemli unsurun güldürü olduğu tespit edilmektedir. Güldürü öğesinin ortalaması oldukça yüksek olarak çıkmıştır. Seri filim ve çizgi film kahramanı ifadeleri düşük olarak çıkmıştır. Bu bağlamda reklamlar oluşturulduğunda mizah ve güldürü ögesinin ön plana çıkarılması reklam izlenme oranını ve etkinliğini artıracaktır.

Tablo 7: Reklamda en çok ilgi çeken unsurların; Ortalama Değer, Standart Sapma ve Kat1lım Düzeyi

\begin{tabular}{|l|r|r|c|}
\hline & Ortalama & Std. Sapma & Katılım Düzeyi \\
\hline Reklamda kullanılan müzik ve ses & 2,91 & 1,135 & Orta \\
\hline Reklamda kullanılan renkler & 2,35 & 1,108 & Orta \\
\hline Reklam ilanında kullanılan karikatürlerin ünlü olması & 2,25 & 1,065 & Düşük \\
\hline Reklamda mizah içerikli bir görsel olması & 4,75 & 0,860 & Yüksek \\
\hline Reklamın yayınlanma sıklığ1 & 2,18 & 1,261 & Düşük \\
\hline Reklamın süresi & 1,03 & 1,523 & Düşük \\
\hline Reklamlarda ünlülerin kullanılması & 2,10 & 1,286 & Düşük \\
\hline Reklamın sevdiğim saatte çıkması & 1,06 & 1,554 & Düşük \\
\hline
\end{tabular}

$\left(\mathrm{x}^{-}=1,00-2,33\right.$ Düşük Katılım Düzeyi, $\mathrm{x}^{-}=2,34-3,66$ Orta Katılım Düzeyi, $\mathrm{x}^{-}=3,67-$

\section{5,00 Yüksek Katılım Düzeyi)}

Reklamda en çok dikkat çeken durum ve satın almayı en çok etkileyen durum "reklamda mizah içerikli bir görselin olması" ifadesi en önemli görülen unsurdur. Söz konusu unsurun katılım düzeyi oldukça yüksektir.

Reklamda en çok ilgi çeken ve satın almayı etkileyen "Reklamda kullanılan müzik ve ses" ile "Reklamda kullanılan renkler" ifadeleridir. Bu ifadelerin katılım düzeyleri orta çıktığı için tüketiciyi daha az etkilemektedir. 
"Reklamın yayınlanma sıklığı”, "Reklamlarda ünlülerin kullanılması", "Reklamın sevdiğim saatte çıkması" ve "Reklamın süresi” ifadelerinin katılım düzeyleri düşük olduğu görülmüştür. $\mathrm{Bu}$ nedenle "Reklamın süresi”, "Reklamın sevdiğim saatte çıkması", "Reklamlarda ünlülerin kullanılması" ve "Reklamın yayınlanma sıklığı" satın almada en az etkili olan ifadelerdir.

\section{SONUÇ}

Sosyal medya, insanları sanal bir şekilde sosyalleştirebilmesinin yanı sıra firmaları da sosyal medya kullanıcıları ile hızlı bir şekilde sosyalleştirmektedir. Özellikle firmaların sosyal medya platformlarında yapmış oldukları kampanya gibi aktivitelere kullanıcılar da katılabilmektedir. Firmalar, hızlı ve düşük maliyetli bir şekilde reklam uygulamalarını doğrudan potansiyel tüketicilere ulaştırabilmektedir. Firmaların temel amacı, tüketicilerin satın alma niyetlerini etkilemek ve kendi ürün ve hizmetlerine yönelik satışları arttırmaktır (Yoldaş ve Özaydın, 2017).

$\mathrm{Bu}$ araştırma sosyal medya reklamlarının tüketici satın alma niyetine etkisini ve daha önceki yapılan çalışmalar ışığında sosyal medya reklamlarını incelemektir. Söz konusu amaca ulaşmak için reklam mecraları, reklam mecralarında takip edilen program türleri, reklamda ilgi çekilen unsur ve reklamda en çok ilgi çeken unsur araştırılmıştır.

Araştırma, ankete katılanların demografik özellikleri, reklam mecraları, reklam mecralarında takip edilen programların türleri, reklamda en etkili olan unsur ve sosyal medya reklamlarında en çok ilgi çeken unsur ile ilgili toplam 28 sorudan oluşmaktadır. Araştırmada ön plana çıkan sonuçlar şu şekilde özetlenebilir.

Bilgi edinmenin önemi sırası ile mobil iletişimde bilgi edinme, radyo dinlerken bilgi edinme, gazete okurken bilgi edinme, televizyon izleme, internette bilgi edinme ve dergi okumanın önemli vurgulanmıştır.

Katılımcıların önemli bir kısmı televizyonda izlendiğinde takip edilen programın haber ve ekonomi olduğu, dergi okunduğunda takip edilen programın haber ve ekonomi olduğu, internette sörf yapıldığında takip edilen programın haber ve ekonomi olduğu, mobil iletişimde bilgi edinilen programın haber ve ekonomi olduğu, radyo dinlerken bilgi aldıkları programın haber ve ekonomi olduğu gazete okurken bilgi aldıkları programın haber ve ekonomi olduğu belirlenmiştir. Dolayısıyla her reklam mecrasında en çok takip edilen programın haber ve ekonomi olduğu söylenebilir.

Reklamda en çok ilgi çeken unsurun güldürü olduğu söylenebilir. 
Reklamda en çok ilgi çeken unsurun reklamda mizah unsurların kullanılması, etkin müzik ve ses, reklam gösterimindeki renkler olduğu en az ilgi çeken unsurun reklamın istenilen saatte çıkmasıdır. Bu bağlamda katılımcıların reklamda en çok ilgilerini çeken unsurun mizah içerikli görsellerin olduğu tespit edilmiştir.

Araştırma 385 tüketici ile yürütülmüştür. Dolayısıyla elde edilen veriler ve sosyal medya reklamlarına yönelik oluşturulan öneriler 385 tüketicinin anket sorularına verdikleri cevaplarla sınırlıdır. Dolayısıyla elde edilen sonuçları genellemek yanlış sonuçlar doğurabilir. Bundan sonra yapılacak çalışmaların araştırma alanlarının genişletilmesi daha genelleştirilebilir sonuçlar açısından önerilmektedir.

Ortalama, Standart Sapma ve Katılım düzeyi göz önüne alındığında en öneli faktörün mizah ve güldürü ögesi olduğu belirlenmiştir. Dolayısıyla şekilsel olarak reklamlar hazırlandığında güldürü unsurunu ön plana çıkarılması reklam izlenme oranını ve etkinliğini artıracaktır.

Reklamda en çok ilgi çeken, reklam etkinliğini artıran unsur "reklamda mizah içerikli bir görsel olması" ifadesidir. "Reklamda kullanılan müzik ve ses" ile "Reklamda kullanılan renkler" ifadeleri ise reklam etkinliğini daha az etkilemektedir.

"Reklamın süresi”, "Reklamın sevdiğim saatte çıkması”, "Reklamlarda ünlülerin kullanılması" ve "Reklamın yayınlanma sıklı̆̆g”" satın almada en az etkili olan ifadelerdir.

\section{Kaynakça}

Altunışık, R., Özdemir, Ş. ve Torlak, Ö. (2006). Modern Pazarlama, Değişim Yayınları, 4. Bask1 Sakarya.

Baudrillard, J. (2017). Tüketim Toplumu, (Çeviren: Hazal Deliceçaylı) Ayrıntı Yayınları.

Can, L. ve Serhateri, A. (2016), 'Sosyal Medya Reklamlarının Markaya Yönelik Tutuma Etkisi: Facebook Üzerinde Bir Uygulama’ Balkan ve Yakın Doğu Sosyal Bilimler Dergisi, Cilt 2, Say1 3, ss. 16-28.

Çağlıyan, V., Işıklar, Z.E. ve Hassan, S.A. (2016). Üniversite Öğrencilerinin Satın Alma Davranışlarında Sosyal Medya Reklamlarının Etkisi: Selçuk Üniversitesi’nde Bir Araştırma. Selçuk Üniversitesi Sosyal ve Teknik Araştırmalar Dergisi, 11, 43-56. 
Göktaş, B. ve Tarakçı, İ.E. (2018), Bir Tutundurma Aracı Olarak Reklamın Sosyal Medyada Uygulamalarına Yönelik Bir Araştırma: Instagram Örneği, Girişimcilik İnovasyon ve Pazarlama Araştırmaları Dergisi Y1l: 2(3), ss. 50-67.

Grönroos, C. (1995) "Relationship Marketing: The Strategy Continuum", Journal of the Academy of Marketing Science, 23(4), pp. 252-254.

Gürdin, B. (2017), Mobil Reklamlar: Yararlı mı? Tavizkâr mı? Organizasyon ve Yönetim Bilimleri Dergisi, 9(2): 1-13.

Gürdin, B. (2017), Sağlık Hizmetleri Sektöründe Reklam Yasağı: Uygulama Örnekleri, Sosyal Ve Beşerî Bilimleri Dergisi, 9(2): 17-30.

İslamoğlu, A.H. (2011), Pazarlama Yönetimi, Beta Yayınları, beşinci Baskı, İstanbul.

Keegan, W.J. ve Green, M.C. (2015), Global Marketing (Küresel Pazarlama), (Çeviren: Rezan Tatlidil), Nobel Yayınları.

Lakshmanan, D. ve Basariya, S.R. (2017), The Role of Social Media on Enhancing Advertising Effectiveness, International Journal of Civil Engineering and Technology (IJCIET), Vol: 8, No: 9, pp. 1042-1047,

Lodziak, C. (2003), İhtiyaçların Manipülasyonu Kapitalizm ve Kültür, (Çev: Berna Kurt), Çitlembik Yayınevi, İstanbul.

MÜSİAD, (2010), Reklam ve Markalaşmada Alternatif Mecralar, MÜSİAD Cep Kitapları İstanbul.

Özkaya, B. (2010), Reklam Aracı Olarak Advergaming. Marmara Üniversitesi İ.İ.B.F. Dergisi, Cilt. 29, ss. 455-478.

Raudeliuniene`, J., Davidavi`ciene, V., Tvaronavi`cien`e, M. ve Jonuška, L. (2018), Evaluation of Advertising Campaigns on Social Media Networks, Sustainability, 10, 973; ss. 1-14.

Süar, A. (2017), Sosyal Medyanın Geleneksel Reklam Araçlarına Göre Hedef Kitle Belirlemedeki Avantajlar1, AJIT-e: Online Academic Journal of Information Technology, Cilt: 8, Sayı: 28, ss. 21-44. 
Tekin, M., Şahin, E. ve Göbenez, Y., (2014), "Postmodern Pazarlama Yaklaşımıyla Modern Pazarlama Yöntemleri: Güncel Şirket Uygulamaları”, Selçuk Üniversitesi Sosyal Bilimler Enstitüsü Dergisi, Dr. Mehmet Yıldız Özel Sayısı, s. 225-232.

Yoldaş, A ve Özaydın, H. (2017), Sosyal Medya Üzerinden Yapılan Reklamların Satın Alma Davranışı Üzerindeki Etkisini Belirlemeye Yönelik Bir Uygulama, Avrasya Sosyal ve Ekonomi Araştırmaları Dergisi (ASEAD), Cilt: 4, Sayı: 12, ss. 781-794. 